Article

\title{
Impact of Short-Range Clustering on the Multistage Work-Hardening Behavior in $\mathrm{Cu}-\mathrm{Ni}$ Alloys
}

\author{
Dong Han, Jin-Xian He, Xian-Jun Guan, Yan-Jie Zhang and Xiao-Wu Li * \\ Department of Materials Physics and Chemistry, School of Materials Science and Engineering, \\ and Key Laboratory for Anisotropy and Texture of Materials, Ministry of Education, Northeastern University, \\ Shenyang 110819, China; handong@stumail.neu.edu.cn (D.H.); he_jinxian@163.com (J.-X.H.); \\ guanxianjun@stumail.neu.edu.cn (X.-J.G.); zhangyanjieneu@163.com (Y.-J.Z.) \\ * Correspondence: xwli@mail.neu.edu.cn; Tel.: +86-24-83678479
}

Received: 7 December 2018; Accepted: 27 January 2019; Published: 29 January 2019

check for updates

\begin{abstract}
The work-hardening behavior of $\mathrm{Cu}-\mathrm{Ni}$ alloys with high stacking-fault energies (SFEs) is experimentally investigated under uniaxial compression. It is found that, with the increase of $\mathrm{Ni}$ content (or short-range clustering, SRC), the flow stress of $\mathrm{Cu}-\mathrm{Ni}$ alloys is significantly increased, which is mainly attributed to an enhanced contribution of work-hardening. An unexpected multistage (including Stages A, B, and C) work-hardening process was found in this alloy, and such a work-hardening behavior is essentially related to the existence of SRC structures in alloys. Specifically, during deformation in Stage B (within the strain range of 0.04-0.07), the forming tendency to planar-slip dislocation structures becomes enhanced with an increase of SRC content (namely, increase of $\mathrm{Ni}$ content), leading to the occurrence of work-hardening rate recovery in the $\mathrm{Cu}-20 \mathrm{at} . \% \mathrm{Ni}$ alloy. In short, increasing SRC in the $\mathrm{Cu}-\mathrm{Ni}$ alloy can trigger an unexpected multistage work-hardening process, and thus improve its work-hardening capacity.
\end{abstract}

Keywords: $\mathrm{Cu}-\mathrm{Ni}$ alloy; work-hardening; short-range clustering; stacking-fault energy; planar slip; dislocation structure

\section{Introduction}

Strength and ductility are two of the most important mechanical properties of metallic materials which usually determine the service environment of materials. However, a large number of experimental results [1-3] show that there is a natural contradiction between strength and ductility which has greatly restrained the application and development of metallic components. As is well known, the ductility is controlled by the work-hardening capacity [4,5]. A high work-hardening capacity can delay the necking and consequent fracture during deformation, leading to a higher ductility. Therefore, some approaches [6-10] were targeted on improving the work-hardening capacity of metallic materials. For examples, Cao et al. [6] introduced intersectant coherent twin boundaries in nanocrystalline $\mathrm{Cu}$, promoting the occurrence of Lomer-Cotrell dislocation locks inside a nanocrystal and resulting in a strong work-hardening behavior. Some further work [8-10] also reported that the work-hardening capacity of metallic materials was improved significantly by introducing a gradient structure, where fine grains undertake strength, while coarse grains ensure work-hardening capacity and thereby decent ductility. Although these attempts provided excellent designing principles and technology, the extremely rigorous and complicated conditions have greatly limited the broad industrial applications.

Recently, alloying was recognized as one simple but effective way to improve the work-hardening capacity for metallic materials $[4,11-15]$. Some research groups $[4,11,12]$ investigated the effect of $\mathrm{Al}$ content on the work-hardening behavior of $\mathrm{Cu}-\mathrm{Al}$ alloys, and they found that the work-hardening 
capacity became enhanced with the increase of Al content. Similar results have also been observed in Cu-Zn [13,14] and Cu-Ge [15] alloys. Kocks and Mecking [16] summarized the physics and phenomenology of work-hardening in the face-centered cubic (FCC) metals. They suggested that the enhancement of the work-hardening capacity in the above-mentioned alloys was ascribed to the decrease in stacking-fault energy (SFE) through increasing solute content, which promoted the formation of deformation twins (DTs) and slip planarity [16].

In some cases, however, the phenomenon that SFE values of alloys decrease evidently with addition of alloying content is not always observed. For example, differing from the case of most $\mathrm{Cu}$-based alloys like $\mathrm{Cu}-\mathrm{Al}$ and $\mathrm{Cu}-\mathrm{Zn}$ alloys, the SFE values of $\mathrm{Cu}-\mathrm{Ni}$ alloys increase obviously with increasing Ni content [17,18]. Nakano and Jacques [19] studied the relationship between SFE and alloying content in the Fe-Mn system by using the least-squares refinement method, and claimed that increasing Mn or C content increases remarkably the SFE. Therefore, an open question is raised: how can the work-hardening capacity of FCC alloys with high SFEs be improved? Actually, research findings reported by some investigators [20-22] have brought us a favorable inspiration. In these studies, it was pointed out that the pronounced planar slip was also observed in $\mathrm{Ni}_{3} \mathrm{Fe}$ and $\mathrm{Cu}-\mathrm{Mn}$ alloys despite the fact that these alloys have quite high SFEs. They suggested that the well-developed short-range order structures in alloys, including short-range order (SRO) or short-range clustering (SRC), promoted planar slip due to the "glide plane softening" effect. As is well known, for metallic alloys, solute atoms do not disperse perfectly at random in alloying matrix, and the solute and solvent atoms in solid solutions are generally apt to form short-range order structures at atomic level. As solute atoms tend to neighbor with solvent atoms, SRO is formed, while SRC tends to form in the case that the solute atoms favor their own segregation [23]. Gerold and Karnthaler [21] believed that the existence of SRO or SRC structures was the crucial factor evoking planar slip in FCC alloys, and other parameters, such as the SFE and yield strength, were only supporting ones. Therefore, it is reasonable to assume that increasing SRC/SRO content in alloys might be a valid strategy for improving the work-hardening capacity of alloys with high SFEs. Unfortunately, much less is known about the influence of SRC/SRO on work-hardening behavior of FCC metals.

The main motivation for the present study is to resolve the above confusion, with a purpose of providing a new idea for designing the microstructure of alloys with high SFEs to realize a good strength-ductility combination. To achieve this goal, three $\mathrm{Cu}-\mathrm{Ni}$ alloys with different Ni contents were chosen as the target materials in this work, because increasing Ni content obviously raises their SFEs [17], but also simultaneously increases the SRC content greatly [24]. Meanwhile, to obtain a complete feature of the work-hardening behavior of $\mathrm{Cu}-\mathrm{Ni}$ alloys, a simple compression test was also adopted, since the occurrence of necking during the tensile process may result in the loss of work-hardening information at large strains [14].

\section{Materials and Methods}

Three kinds of $\mathrm{Cu}-\mathrm{xNi}$ alloys ( $\mathrm{x}=5,10,20$ at.\%) were fabricated using an induction melting furnace and cast into ingots with a dimension of $60 \mathrm{~mm} \times 100 \mathrm{~mm} \times 300 \mathrm{~mm}$. These ingots were homogenized at $700{ }^{\circ} \mathrm{C}$ for $2 \mathrm{~h}$ and then immediately hot-rolled into 10 -mm-thick plates along the $60 \mathrm{~mm}$ side of ingots, followed by air cooling. Rectangular specimens of $8 \mathrm{~mm} \times 8 \mathrm{~mm} \times 12 \mathrm{~mm}$ in size were cut from as-rolled plates. To eliminate the impact of the diversity in grain size on work-hardening behavior, these compression specimens were subjected to a recrystallization annealing treatment for 20-24 h at 900-1000 ${ }^{\circ} \mathrm{C}$ in vacuum and then water-quenched, acquiring a comparable grain size. Before compression tests, all specimens were ground and electropolished to produce a strain-free and smooth surface.

Compression tests were performed on a CMT5101 machine (Shenzhen SANS Testing Machine Co. Ltd., Shenzhen, China) at ambient temperature with an initial strain rate of $10^{-3} \mathrm{~s}^{-1}$ up to an engineering strain of $30 \%$. The direction of the compression axis is parallel to the rolling direction of the rolled plate. After mechanical tests, internal microstructures were clarified by transmission electron 
microscopy (TEM) using an FEI Tecnai $\mathrm{G}^{2} 20$ (FEI, Hillsbro, OR, USA) operated at $200 \mathrm{kV}$. TEM samples were spark-cut from the specimens along the loading axis after compression deformation up to true strains of $5 \%$ and $30 \%$, respectively. Slices were first manually reduced to $\sim 60 \mu \mathrm{m}$ and then thinned by twin-jet electropolishing in a solution of $90 \%$ ethanol and $10 \%$ perchloric acid with a voltage of $20 \mathrm{~V}$ at $-30{ }^{\circ} \mathrm{C}$.

\section{Results and Discussion}

Representative optical micrographs of initial microstructures of $\mathrm{Cu}-\mathrm{Ni}$ alloy specimens are shown in Figure 1. All specimens exhibit homogeneous microstructures with a similar grain size of about $280 \mu \mathrm{m}$, and no second phase was detected in all materials, making it more feasible and simpler to explore solely the impact of SRC on the work-hardening behavior and microstructural evolution in these alloys.

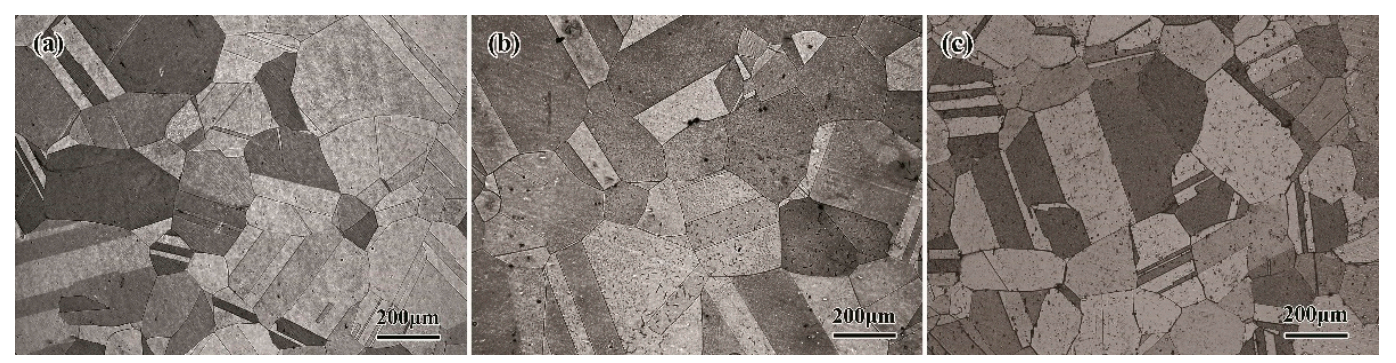

Figure 1. Optical microscope (OM) images showing the original microstructures of $\mathrm{Cu}-\mathrm{Ni}$ alloys containing 5 at.\% Ni (a), 10 at.\% Ni (b), and 20 at.\% Ni (c).

\subsection{Compressive Mechanical Property}

Figure 2a shows the true stress-strain curves of $\mathrm{Cu}-\mathrm{Ni}$ alloys with different $\mathrm{Ni}$ contents in compression at room temperature. Apparently, with increasing $\mathrm{Ni}$ content, the flow stress of $\mathrm{Cu}-\mathrm{Ni}$ alloys is significantly increased. The yield strength (YS) of the Cu-20at.\% Ni alloy is enhanced from 35 to $70 \mathrm{MPa}$ compared with that of the $\mathrm{Cu}-5$ at.\% Ni alloy, which mainly stems from the solid solution strengthening owing to the increase of Ni content [24]. It is noteworthy that, after yielding, the flow stress of $\mathrm{Cu}-\mathrm{Ni}$ alloys exhibits a significant elevation with increasing $\mathrm{Ni}$ content. For the present $\mathrm{Cu}-\mathrm{Ni}$ alloy specimens, the total flow stress at a given strain can be considered as the sum of YS $\left(\sigma_{0.2}\right)$ and the stress originating from work-hardening $\left(\sigma_{\mathrm{WH}}\right)$. Therefore, the contributions of work-hardening to the flow stress can be roughly estimated by subtracting the YS from the total flow stress as

$$
\sigma_{\mathrm{WH}}=\sigma_{\mathrm{FS}}-\sigma_{0.2}
$$

where $\sigma_{\mathrm{FS}}$ is the flow stress of $\mathrm{Cu}-\mathrm{Ni}$ alloys at a given strain. According to Equation (1), the distribution of the $\sigma_{\mathrm{WH}}$ of the $\mathrm{Cu}-\mathrm{Ni}$ alloys at different strains is given in Figure $2 \mathrm{~b}$. Interestingly, as the true strain is below $\sim 0.05$, the contributions of work-hardening to the flow stress are almost the same in these three $\mathrm{Cu}-\mathrm{Ni}$ alloys. However, as the true strain increases to as high as 0.05 , such contributions are dramatically enhanced with the increase of Ni content, implying that the Ni content plays a crucial role in improving the work-hardening behavior of $\mathrm{Cu}-\mathrm{Ni}$ alloys.

As is well known, the relation between the $\sigma_{\mathrm{WH}}$ and the total dislocation density $(\rho)$ is given by [25]

$$
\sigma_{\mathrm{WH}}=M \alpha G b \sqrt{\rho}
$$

where $G$ is the shear modulus, $b$ the Burgers vector, $M$ the Taylor factor, and $\alpha$ is a material constant. Since all specimens experienced a very strong annealing process, it can be assumed that there are nearly no dislocations in the internal microstructure of specimens before compression tests. Therefore, the enhancement of flow stress by work-hardening in $\mathrm{Cu}-\mathrm{Ni}$ alloys with increasing $\mathrm{Ni}$ content should 
be derived from the higher dislocation density induced during deformation. Similar phenomena have been found in some other $\mathrm{Cu}$ alloys, such as $\mathrm{Cu}-\mathrm{Zn}$ [13] and $\mathrm{Cu}-\mathrm{Al}$ [4] alloys. In these studies, the increase in dislocation density was related to the reduction in SFE. Specifically, on the one hand, decreasing SFE can enlarge the separation between two partial dislocations, which makes cross slip or climb more difficult, thereby inhibiting potential dynamic recovery. On the other hand, a drop in SFE is also favorable for the formation of DTs, which provide accommodations for dislocation accumulation to increase the dislocation density. However, such explanations are inapplicable to the present $\mathrm{Cu}-\mathrm{Ni}$ alloys with high SFEs, since cross slip is prevalent, which aggravates dislocation annihilations during deformation [26,27]. In fact, in addition to altering the SFE, the addition of alloying elements brings about a positive effect on the increase of SRO/SRC in alloys $[23,28,29]$. Considering that the SRC/SRO could suppress the cross slip [21], it is believed that the increasing degree of SRC due to the addition of $\mathrm{Ni}$ element should be a reason for the enhancement of dislocation density in the present $\mathrm{Cu}-\mathrm{Ni}$ alloys, leading to a stronger work-hardening capacity.
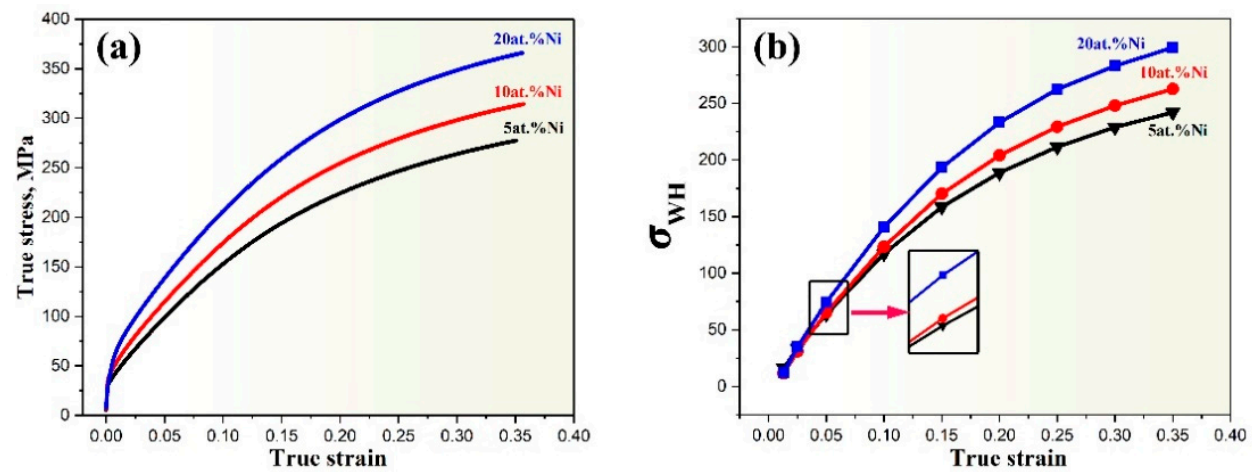

Figure 2. Mechanical properties of $\mathrm{Cu}-\mathrm{Ni}$ alloys under uniaxial compression. (a) True stress-strain curves; (b) the distribution of the $\sigma_{\mathrm{WH}}$ of $\mathrm{Cu}-\mathrm{Ni}$ alloys at different strains.

\subsection{Unexpected Multistage Work-Hardening Behavior of $\mathrm{Cu}-\mathrm{Ni}$ Alloys}

The work-hardening rate $\left(\mathrm{d} \sigma_{\text {true }} / \mathrm{d} \varepsilon_{\text {true }}\right)$ is an important index for the evaluation of the work-hardening capacity of alloys, which reflects the uniform deformation ability during deformation. Therefore, the change of work-hardening rate with true strain for the present $\mathrm{Cu}-\mathrm{Ni}$ alloys is given in Figure 3. It is found that the work-hardening rate of $\mathrm{Cu}-\mathrm{Ni}$ alloys also becomes significantly improved with increasing Ni content. More importantly, a multistage work-hardening process is discovered in the present $\mathrm{Cu}-\mathrm{Ni}$ alloys. This result is unexpected, since the work-hardening rate of alloys with high SFEs normally decreases monotonically with increasing strain [16,30].

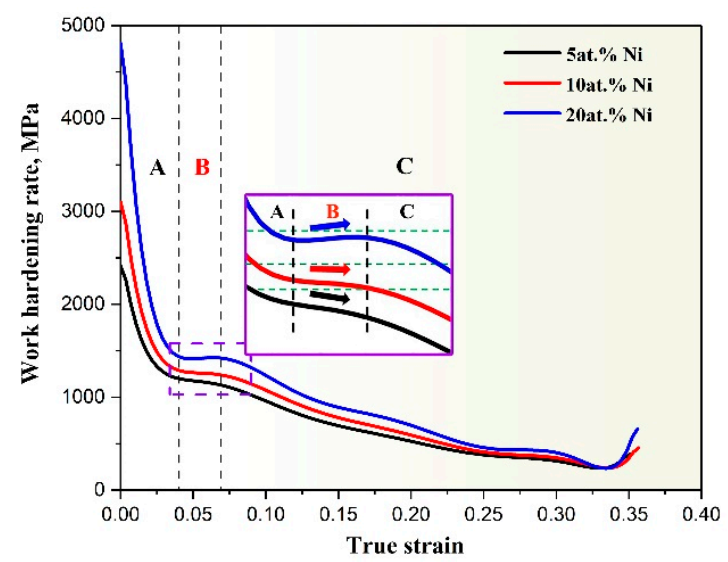

Figure 3. The curves of the work-hardening rate vs the true strain for $\mathrm{Cu}-\mathrm{Ni}$ alloys. 
As seen from Figure 3, in Stage A, the work-hardening rate of three $\mathrm{Cu}-\mathrm{Ni}$ alloys sharply decreases as a consequence of elastoplastic transition [31,32]. It should be noted that these curves in Stage A are almost parallel to each other, implying that the evolutional rate of dislocation density is almost the same at the very beginning of plastic deformation. That is to say, the differences in the work-hardening capacity of these three alloys in Stage A are not obvious, coinciding well with the phenomenon that the contributions of work-hardening to the flow stress is almost the same in these three $\mathrm{Cu}-\mathrm{Ni}$ alloy samples as the true strain is lower than 0.05 (Figure 2b). Even so, a higher Ni content still exhibits a beneficial effect on suppressing rapid decline of work-hardening rate. A direct evidence is that, with the increase of Ni addition, the work-hardening rate at the Stage A-Stage B transition is enhanced from 1204 to $1440 \mathrm{MPa}$.

Stage A is followed by Stage B (i.e., at strains roughly in the range of 0.04-0.07), where the $\mathrm{Ni}$ content strongly influences the shape of the work-hardening rate curves. For the $\mathrm{Cu}-5$ at.\% $\mathrm{Ni}$ alloy, the work-hardening rate decreases slowly with increasing strain in Stage $\mathrm{B}$, while, for the $\mathrm{Cu}-10 \mathrm{at} . \% \mathrm{Ni}$ alloy, the work-hardening rate almost stays unchanged at a constant level. In contrast, a phenomenon of work-hardening rate recovery is observed in the $\mathrm{Cu}-20 \mathrm{at} . \% \mathrm{Ni}$ alloy (i.e., the work-hardening rate increases with the increase of strain). The Stage B formed in the present $\mathrm{Cu}-\mathrm{Ni}$ alloys is of special attention because this phenomenon had been previously reported as a peculiar trait of FCC metals with low SFE, such as $\mathrm{Cu}-\mathrm{Al}$ [4,33], Cu-Zn [14], and IN625 [34] alloys; it was attributed to the occurrence of DTs, planar slip, or stacking faults, caused by SFE lowering in these alloys. In view of the fact that SRO structures could also effectively promote the planar slip of dislocations in high-SFE FCC alloys [21], it is reasonable to infer that the occurrence of the anomalous Stage B in the present $\mathrm{Cu}-\mathrm{Ni}$ alloys is essentially related to the existence of SRC structures in alloys, which will be further discussed by observing the corresponding deformation microstructures.

Stage $\mathrm{C}$ is characterized by a second decreasing of work-hardening rate for all $\mathrm{Cu}-\mathrm{Ni}$ alloys. Compared to the steep slope of the work-hardening rate curves in Stage A, the work-hardening rates of $\mathrm{Cu}-\mathrm{Ni}$ alloys in Stage $\mathrm{C}$ decrease much more slowly with increasing strain until they approach zero. Besides, the work-hardening rate of the $\mathrm{Cu}-20$ at.\% $\mathrm{Ni}$ alloy exhibits a slower downward trend than those of the $\mathrm{Cu}-5 \mathrm{at} . \% \mathrm{Ni}$ and $\mathrm{Cu}-10 \mathrm{at} . \% \mathrm{Ni}$ alloys. Two mechanisms have been proposed in the previous investigations $[14,16,35]$ on the work-hardening behavior of FCC metals to uncover the cause of Stage C: a reduction in the rate of producing DTs and an increase in ability of dislocation cross slip. For $\mathrm{Cu}-\mathrm{Ni}$ alloys, the former mechanism can be ignored because of the high SFEs of alloys themselves, and a second decreasing in Stage $\mathrm{C}$ in $\mathrm{Cu}-\mathrm{Ni}$ alloys might thus be considered as a result of cross-slip activation. It means that the SFE dominates the work-hardening behavior of Stage C, and the influence of SRCs becomes weakened.

In short, the influence of $\mathrm{Ni}$ content on the work-hardening behavior of $\mathrm{Cu}-\mathrm{Ni}$ alloys is complicated. The work-hardening rate of Stages B and C is markedly improved with increasing $\mathrm{Ni}$ content, which results in a higher work-hardening capacity. Therefore, to gain insight into the impact of the Ni content on Stages B and C, the corresponding deformation microstructures were investigated by TEM observations, as representatively shown in Figures 4 and 5 .

\subsection{Microstructural Evolution}

Figure 4 shows the TEM images of typical microstructures for the three $\mathrm{Cu}-\mathrm{Ni}$ alloys compressed up to a true strain of $5 \%$, which corresponds approximately to the middle part of Stage B. No deformation twins and stacking faults are detected for all alloys. For the $\mathrm{Cu}-5 \mathrm{at} . \% \mathrm{Ni}$ alloy, the dislocation density is low and dislocation lines and loose tangles are distributed in the field randomly, showing an underdeveloped wavy-slip dislocation configuration (Figure 4a). As the Ni content is raised to 10 at. $\%$, the dislocation density is slightly increased, and some planar-like slip structures tend to form (Figure $4 \mathrm{~b}$ ). As the Ni content is as high as 20 at. $\%$, distinct planar-slip structures with a relatively high dislocation density dominate the substructural characteristics, accompanied by a few dislocation tangles in local regions (Figure 4c,d). Meanwhile, the activity of the dislocations in the 
secondary slip system can be clearly observed (marked by red line in Figure 4c,d). The results above clearly indicate that, with increasing Ni content, the predominant deformation mechanism of $\mathrm{Cu}-\mathrm{Ni}$ alloys in Stage B transfers from wavy slip to planar slip. For the present $\mathrm{Cu}-\mathrm{Ni}$ alloys, their SFEs are very high and the increase of SRC degree should thus be the main reason for the planar slip of dislocations, which was interpreted as "glide plane softening" effect [21].

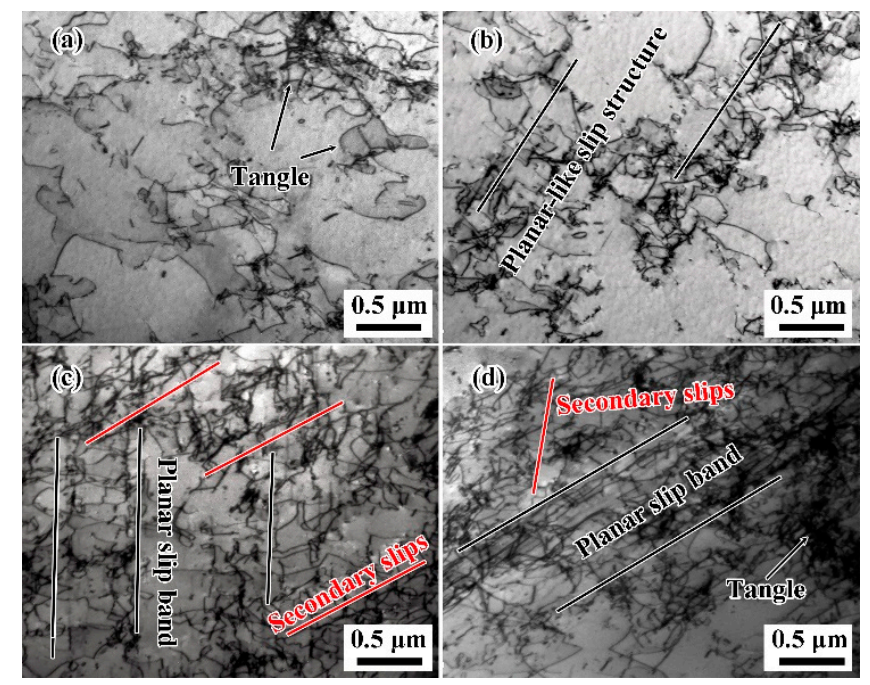

Figure 4. TEM images of dislocation structures of $\mathrm{Cu}-\mathrm{Ni}$ alloys containing 5 at.\% $\mathrm{Ni}(\mathbf{a}), 10$ at.\% Ni (b), and 20 at. $\% \mathrm{Ni}(\mathbf{c}, \mathbf{d})$ uniaxially compressed up to a true strain of $5 \%$.

As experimentally revealed and analyzed above, the SRC has a significant effect on the microstructural evolution in Stage B of $\mathrm{Cu}-\mathrm{Ni}$ alloys, and consequently on the work-hardening behavior in Stage B, as explained in detail below.

For the $\mathrm{Cu}-5$ at.\% Ni alloy, although the lower SRC cannot overcome the influence of high SFE, the presence of SRC restrains dynamic recovery to some extent. As a result, an ill-developed wavy-slip dislocation structure is just observed in Stage B. For this reason, the work-hardening rate of $\mathrm{Cu}-5 \mathrm{at} . \%$ $\mathrm{Ni}$ alloy does not go on falling quickly but exhibits a slow decline in Stage B. For the $\mathrm{Cu}-10 \mathrm{at} . \% \mathrm{Ni}$ alloy, planar-like slip structures are formed in Stage B due to the increase in SRC content. In contrast to pure wavy-slip dislocation structures, planar-like slip structures reduce the dislocation mean free path $(L)$, and thus the rate of dislocation storage becomes enlarged, which balances the softening effect of dynamic recovery according to the Kocks-Mecking model [16]. Consequently, the Cu-10at.\% $\mathrm{Ni}$ alloy shows a nearly constant work-hardening rate in Stage B. With further increases of SRC, the deformation microstructures have become dominated by planar slip in the $\mathrm{Cu}-20 \mathrm{at} . \% \mathrm{Ni}$ alloy. On the one hand, planar-slip dislocation structures notably inhibit dynamic recovery, that is, annihilation of screw dislocations is hindered. On the other hand, the formation of planar-slip dislocation structures can ensure a long-lasting hardening potential. Actually, unlike wavy slip, for planar-slip materials, the primary slips are mainly concentrated on several slip planes in the early stage of deformation and other areas might be totally slip-band-free. Therefore, the dislocations in the secondary slip system could be readily activated at a very low strain or stress owing to the weak latent hardening of planar slip [36,37]. This can be confirmed by the formation of secondary slips (Figure 4c,d). Accordingly, the $L$ of mobile dislocations would be sharply shortened due to the interaction between dislocations in the primary and secondary slip systems; in this case, dislocation density must increase suddenly, leading to the occurrence of work-hardening rate recovery in Stage B of the $\mathrm{Cu}-20 \mathrm{at} . \% \mathrm{Ni}$ alloy. In brief, the increment of the SRC content effectively promotes the occurrence of planar slip in Stage B for the present $\mathrm{Cu}-\mathrm{Ni}$ alloys, and enhances the work-hardening rate.

Figure 5 displays the TEM images of typical microstructures for the three $\mathrm{Cu}-\mathrm{Ni}$ alloys compressed up to a true strain of $30 \%$, which is roughly located at the end of Stage C. Evidently, with increasing 
strain, the dislocation density of the present alloy specimens increases remarkably. It is worth paying special attention to the absence of planar-slip dislocation structures in Stage C, where wavy-slip dislocation structures become dominated in all $\mathrm{Cu}-\mathrm{Ni}$ alloys. However, a significant difference in dislocation configuration among these three $\mathrm{Cu}-\mathrm{Ni}$ alloys can be observed. For the $\mathrm{Cu}-5 \mathrm{at} . \% \mathrm{Ni}$ alloy, the dislocation cells are the most common microstructures (Figure 5a), which are almost analogous to those in pure $\mathrm{Cu}$ [38]. As the Ni content is increased to 10 at.\%, extended dislocation cells can be frequently observed (Figure 5b). Moreover, the width of extended cells is much smaller than the size of cells in the $\mathrm{Cu}-5$ at.\% Ni alloy. As the Ni content is as high as 20 at.\%, the dislocation structures have been featured by highly ordered cell walls with an increased dislocation density, as seen in Figure 5c. The orientation of these walls with high-density dislocations is parallel to each other and ordinary dislocation cells are densely distributed between these walls. Based on the observations above, it can be recognized that the suppressive effect of SRC on cross slip is negligible in Stage C and wavy-slip dislocation structures are consequently formed. A similar result was also found in the $\mathrm{Cu}-10 \mathrm{at}$ \% $\mathrm{Mn}$ alloy with high SFE reported by Ma et al. [39]. In reality, this phenomenon can be well understood in the following way: with increasing strain, the SRC in $\mathrm{Cu}-\mathrm{Ni}$ alloys will be gradually destroyed by moving dislocations, since it is only of a short range. As a result, cross slip becomes prevalent due to the high SFE of $\mathrm{Cu}-\mathrm{Ni}$ alloys, resulting in the formation of wavy-slip dislocation structures. However, it should be noted that the diversity in wavy-slip dislocation configurations in Stage C among three $\mathrm{Cu}-\mathrm{Ni}$ alloys is intrinsically related to the difference in dislocation structures already formed in Stage B. Recently, a detailed study by Gutierrez-Urrutia and Raabe [40] on the dislocation and twin substructure evolution in Fe-22wt.\% Mn-0.6wt.\% C TWIP steel supports this argument to a certain extent. In their work, the formation mechanism of dislocation cell wall structures was revealed clearly using an electron channeling contrast imaging technique, and they reported that the formation of dislocation walls was attributed to high development of planar slip at the preliminary stage of deformation, while the activation of wavy slip with increasing strain leads to the formation of dislocation cells [40].
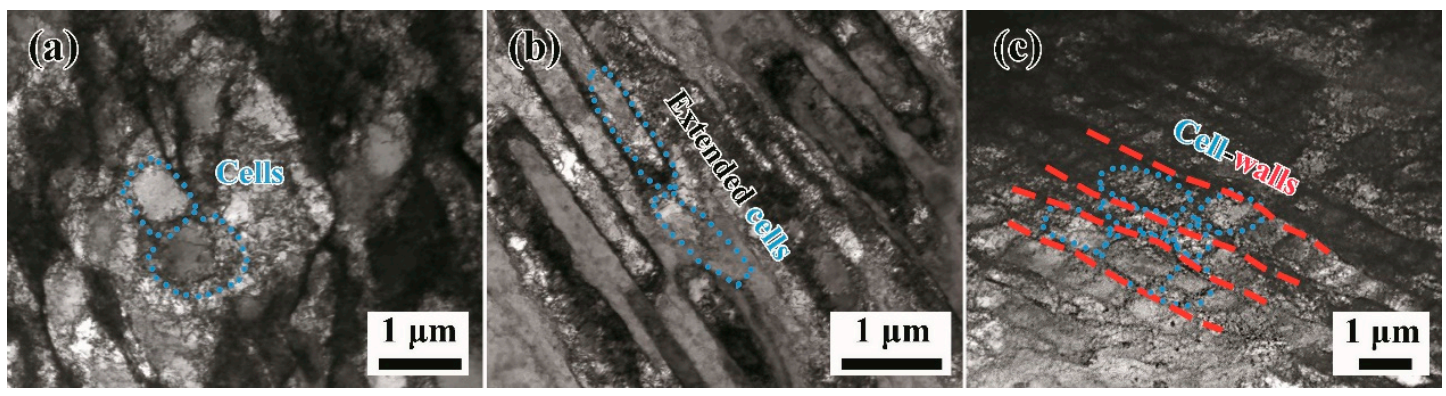

Figure 5. TEM images of different kinds of dislocation structures of $\mathrm{Cu}-\mathrm{Ni}$ alloys uniaxially compressed up to a true strain of 30\%. (a) Dislocation cells in the Cu-5at.\% Ni alloy, (b) extended cells in the $\mathrm{Cu}-10 \mathrm{at} . \% \mathrm{Ni}$ alloy, and (c) oriented cell walls in the $\mathrm{Cu}-20 \mathrm{at} . \% \mathrm{Ni}$ alloy.

Based on the observation and analysis of deformation microstructures, the decrease of work-hardening rate in Stage $\mathrm{C}$ for three $\mathrm{Cu}-\mathrm{Ni}$ alloys can be put down to the prevalence of dislocation cross slip due to the consumption of SRC by moving dislocations. As a result, dynamic recovery mechanism dominates the work-hardening process of Stage C. Nevertheless, the important influence of dislocation substructures on dynamic recovery should not be ignored. Comparing with the dislocation cells formed in the $\mathrm{Cu}-5$ at.\% $\mathrm{Ni}$ and $\mathrm{Cu}-10$ at.\% $\mathrm{Ni}$ alloys, the dislocation walls in the $\mathrm{Cu}-20$ at.\% Ni alloy could not only act as valid barriers to dislocation motion, but also trap some dislocations by boundaries and thereby reduce the rate of dynamic recovery [40]. Consequently, the Cu-20at.\% Ni alloy still exhibits a higher work-hardening rate in Stage C.

Figure 6 displays the impact of SRC on the work-hardening behavior of $\mathrm{Cu}-\mathrm{Ni}$ alloys in a schematic way, and the corresponding microstructural evolution is also clearly shown. At the beginning 
of deformation, the existence of SRC interrupts the rapid drop of work-hardening rate in Stage A for $\mathrm{Cu}-\mathrm{Ni}$ alloys. With increasing strain to Stage B, the interaction between glissile dislocations and SRC structures in alloys becomes significant, leading to a gradual change of slip mode from wavy slip to planar slip with increasing SRC. The occurrence of these planar slips makes for dislocation storage and inhibits dynamic recovery, thus enhancing the work-hardening rate. However, with further increasing strain to Stage C, SRC is gradually consumed by moving dislocations, and activation of cross slip becomes easier, so that wavy-slip dislocation structures tend to form. In this case, dynamic recovery is enhanced, causing a second decrease in the work-hardening rate. In short, increasing SRC triggers an unexpected multistage work-hardening process, which improves the work-hardening capacity of $\mathrm{Cu}-\mathrm{Ni}$ alloys with high SFE.

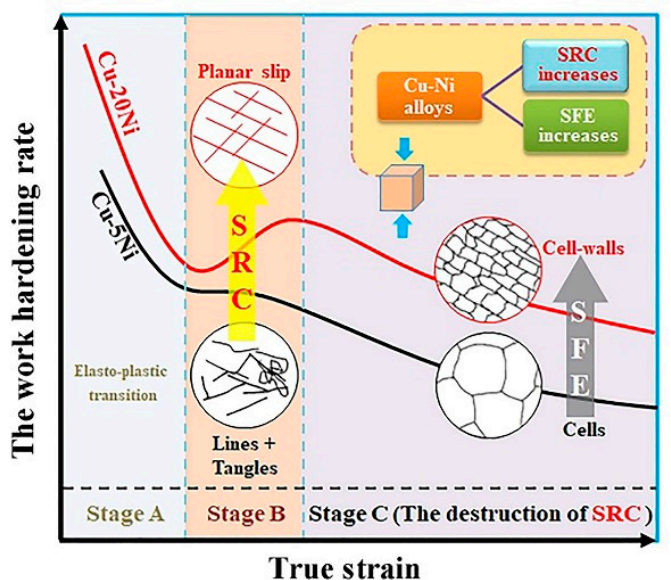

Figure 6. Schematic illustration showing the influence of SRC on the work-hardening behavior and deformation microstructures of $\mathrm{Cu}-\mathrm{Ni}$ alloys.

\section{Conclusions}

The influence of SRC on the work-hardening behavior of $\mathrm{Cu}-\mathrm{Ni}$ alloys with high SFE was investigated under uniaxial compression. The following conclusions can be drawn.

(1) An unexpected multistage (including Stages A, B, and C) work-hardening process was found in high-SFE $\mathrm{Cu}-\mathrm{Ni}$ alloys. With the increase of Ni content (or SRC content), the flow stress of $\mathrm{Cu}-\mathrm{Ni}$ alloys is significantly increased, which is mainly attributed to the improvement of work-hardening capacity.

(2) The work-hardening behavior of Stage B strongly depends on the SRC content in $\mathrm{Cu}-\mathrm{Ni}$ alloys. With increasing SRC content, a gradual transition of dislocation structures occurs from loose tangles to planar-slip structures, which effectively suppress dislocation cross slip and increase the density of movable dislocations during deformation. Consequently, a noticeable recovery of work-hardening rate was found in Stage B in the $\mathrm{Cu}-20$ at.\% Ni alloy.

(3) With increase of strain to Stage $\mathrm{C}$, a second decrease of work-hardening rate was observed for all $\mathrm{Cu}-\mathrm{Ni}$ alloys, ascribing to the prevalence of dislocation cross slip due to the overall destruction of SRC by moving dislocations. The oriented cell walls structures formed in the $\mathrm{Cu}-20 \mathrm{at} . \% \mathrm{Ni}$ alloy can, more or less, relieve the rate of dynamic recovery of dislocations, so that it still exhibits a higher work-hardening rate in this stage.

Author Contributions: X.-W.L. designed the scope of the paper. D.H., J.-X.H., X.-J.G., and Y.-J.Z. performed experiments; D.H. and X.-W.L. analyzed the experimental results; D.H. drafted the initial manuscript and X.-W.L. shaped it into the final form.

Funding: This work was financially supported by the National Natural Science Foundation of China (NSFC) under Grant nos. 51571058 and 51871048.

Conflicts of Interest: The authors declare no conflict of interest. 


\section{References}

1. Rai, R.K.; Sahu, J.K. Strength-ductility paradox in a directionally solidified nickel base superalloy. Mater. Lett. 2018, 220, 90-93. [CrossRef]

2. Nene, S.S.; Frank, M.; Liu, K.; Sinha, S.; Mishra, R.S.; McWilliams, B.; Cho, K.C. Reversed strength-ductility relationship in microstructurally flexible high entropy alloy. Scr. Mater. 2018, 154, 163-167. [CrossRef]

3. Dang, B.; Zhang, X.; Chen, Y.Z.; Chen, C.X.; Wang, H.T.; Liu, F. Breaking through the strength-ductility trade-off dilemma in an Al-Si-based casting alloy. Sci. Rep. 2016, 6, 30874. [CrossRef] [PubMed]

4. Tian, Y.Z.; Zhao, L.J.; Park, N.; Liu, R.; Zhang, P.; Zhang, Z.J.; Shibata, A.; Zhang, Z.F.; Tsuji, N. Revealing the deformation mechanisms of $\mathrm{Cu}-\mathrm{Al}$ alloys with high strength and good ductility. Acta Mater. 2016, 110, 61-72. [CrossRef]

5. Zhang, D.D.; Zhang, D.P.; Bu, F.Q.; Li, X.L.; Li, B.S.; Yan, T.L.; Guan, K.; Yang, Q.; Liu, X.J.; Meng, J. Excellent ductility and strong work hardening effect of as-cast $\mathrm{Mg}-\mathrm{Zn}-\mathrm{Zr}-\mathrm{Yb}$ alloy at room temperature. J. Alloys Compd. 2017, 728, 404-412. [CrossRef]

6. Cao, Z.H.; Sun, W.; Yang, X.B.; Zhao, J.W.; Ma, Y.J.; Meng, X.K. Intersectant coherent twin boundaries governed strong strain hardening behavior in nanocrystalline Cu. Int. J. Plasticity 2018, 103, 81-94. [CrossRef]

7. Ning, J.L.; Xu, B.; Sun, M.S.; Zhao, C.Y.; Feng, Y.L.; Tong, W.P. Strain hardening and tensile behaviors of gradient structure mg alloys with different orientation relationships. Mater. Sci. Eng. A 2018, 735, 275-287. [CrossRef]

8. Yang, X.C.; Ma, X.L.; Moering, J.; Zhou, H.; Wang, W.; Gong, Y.L.; Tao, J.M.; Zhu, Y.T.; Zhu, X.K. Influence of gradient structure volume fraction on the mechanical properties of pure copper. Mater. Sci. Eng. A 2015, 645, 280-285. [CrossRef]

9. Yin, Z.; Yang, X.C.; Ma, X.L.; Moering, J.; Yang, J.; Gong, Y.L.; Zhu, Y.T.; Zhu, X.K. Strength and ductility of gradient structured copper obtained by surface mechanical attrition treatment. Mater. Des. 2016, 105, 89-95. [CrossRef]

10. Wu, X.L.; Yang, M.X.; Yuan, F.P.; Chen, L.; Zhu, Y.T. Combining gradient structure and trip effect to produce austenite stainless steel with high strength and ductility. Acta Mater. 2016, 112, 337-346. [CrossRef]

11. Qu, S.; An, X.H.; Yang, H.J.; Huang, C.X.; Yang, G.; Zang, Q.S.; Wang, Z.G.; Wu, S.D.; Zhang, Z.F. Microstructural evolution and mechanical properties of $\mathrm{Cu}-\mathrm{Al}$ alloys subjected to equal channel angular pressing. Acta Mater. 2009, 57, 1586-1601. [CrossRef]

12. Rohatgi, A.; Vecchio, K.S.; Gray, G.T., III. A metallographic and quantitative analysis of the influence of stacking fault energy on shock-hardening in $\mathrm{Cu}$ and $\mathrm{Cu}-\mathrm{Al}$ alloys. Acta Mater. 2001, 49, 427-438. [CrossRef]

13. Zhang, P.; An, X.H.; Zhang, Z.J.; Wu, S.D.; Li, S.X.; Zhang, Z.F.; Figueiredo, R.B.; Gao, N.; Langdon, T.G. Optimizing strength and ductility of $\mathrm{Cu}-\mathrm{Zn}$ alloys through severe plastic deformation. Scr. Mater. 2012, 67, 871-874. [CrossRef]

14. Asgari, S.; El-Danaf, E.; Kalidindi, S.R.; Doherty, R.D. Strain hardening regimes and microstructural evolution during large strain compression of low stacking fault energy FCC alloys that form deformation twins. Metall. Mater. Trans. A 1997, 28, 1781-1795. [CrossRef]

15. Gong, Y.L.; Wen, C.E.; Wu, X.X.; Ren, S.Y.; Cheng, L.P.; Zhu, X.K. The influence of strain rate, deformation temperature and stacking fault energy on the mechanical properties of $\mathrm{Cu}$ alloys. Mater. Sci. Eng. A 2013, 583, 199-204. [CrossRef]

16. Kocks, U.F.; Mecking, H. Physics and phenomenology of strain hardening: The FCC case. Prog. Mater. Sci. 2003, 48, 171-273. [CrossRef]

17. Nakajima, K.; Numakura, K. Effect of solute atoms on stacking faults $\mathrm{Cu}-\mathrm{Ni}$ and $\mathrm{Cu}-\mathrm{Mn}$ systems. Philos. Mag. A 1965, 12, 361-368. [CrossRef]

18. Lu, S.; Hu, Q.M.; Delczeg-Czirjak, E.K.; Johansson, B.; Vitos, L. Determining the minimum grain size in severe plastic deformation process via first-principles calculations. Acta Mater. 2012, 60, 4506-4513. [CrossRef]

19. Nakano, J.; Jacques, P.J. Effects of the thermodynamic parameters of the hcp phase on the stacking fault energy calculations in the Fe-Mn and Fe-Mn-C systems. Calphad 2010, 34, 167-175. [CrossRef]

20. Karnthaler, H.P.; Schügerl, B. Dislocation structures in plastically deformed, disordered Ni3Fe. In Strength of Metals and Alloys, Proceedings of the 5th International Conference, Aachen, GER, 27-31 August 1979; Haasen, P., Gerold, V., Kostorz, G., Eds.; Pergamon Press: Oxford, UK, 1979; pp. 205-210. 
21. Gerold, V.; Karnthaler, H.P. On the origin of planar slip in f.c.c. alloys. Acta Metall. 1989, 37, $2177-2183$. [CrossRef]

22. Han, D.; Wang, Z.Y.; Yan, Y.; Shi, F.; Li, X.W. A good strength-ductility match in Cu-Mn alloys with high stacking fault energies: Determinant effect of short range ordering. Scr. Mater. 2017, 133, 59-64. [CrossRef]

23. Hong, H.L.; Wang, Q.; Dong, C. Composition formulas of $\mathrm{Cu}-\mathrm{Ni}$ industrial alloy specifications. Sci. China Mater. 2015, 58, 355-362. [CrossRef]

24. Wang, Z.Y.; Han, D.; Li, X.W. Competitive effect of stacking fault energy and short-range clustering on the plastic deformation behavior of Cu-Ni alloys. Mater. Sci. Eng. A 2017, 679, 484-492. [CrossRef]

25. Taylor, G.I. The mechanism of plastic deformation of crystals. Part I.-Theoretical. Proc. R. Soc. Lond. 1934, 145, 362-387. [CrossRef]

26. Li, P.; Li, S.X.; Wang, Z.G.; Zhang, Z.F. Fundamental factors on formation mechanism of dislocation arrangements in cyclically deformed FCC single crystals. Prog. Mater. Sci. 2011, 56, 328-377. [CrossRef]

27. Argon, A.S.; Haasen, P. A new mechanism of work hardening in the late stages of large strain plastic flow in F.C.C. and diamond cubic crystals. Acta Metall. Mater. 1993, 41, 3289-3306. [CrossRef]

28. Pfeiler, W. Investigation of short-range order by electrical resistivity measurement. Acta Metall. 1988, 36, 2417-2434. [CrossRef]

29. Perrier, J.P.; Tissier, B.; Tournier, R. Nearest-neighbor model of magnetism for copper-nickel alloys and clustering of magnetic moments. Phys. Rev. Lett. 1970, 24, 313-316. [CrossRef]

30. Hamdi, F.; Asgari, S. Influence of stacking fault energy and short-range ordering on dynamic recovery and work hardening behavior of copper alloys. Scr. Mater. 2010, 62, 693-696. [CrossRef]

31. Mittra, J.; Dubey, J.S.; Kulkarni, U.D.; Dey, G.K. Role of dislocation density in raising the stage II work-hardening rate of alloy 625. Mater. Sci. Eng. A 2009, 512, 87-91. [CrossRef]

32. Kula, A.; Jia, X.; Mishra, R.K.; Niewczas, M. Flow stress and work hardening of Mg-Y alloys. Int. J. Plasticity 2017, 92, 96-121. [CrossRef]

33. Tian, Y.Z.; Zhao, L.J.; Chen, S.; Shibata, A.; Zhang, Z.F.; Tsuji, N. Significant contribution of stacking faults to the strain hardening behavior of $\mathrm{Cu}-15 \% \mathrm{Al}$ alloy with different grain sizes. Sci. Rep. 2015, 5, 16707. [CrossRef] [PubMed]

34. Hamdi, F.; Asgari, S. Evaluation of the role of deformation twinning in work hardening behavior of face-centered-cubic polycrystals. Metall. Mater. Trans. A 2008, 39, 294-303. [CrossRef]

35. Liu, T.T.; Pan, F.S.; Zhang, X.Y. Effect of Sc addition on the work-hardening behavior of ZK60 magnesium alloy. Mater. Des. 2013, 43, 572-577. [CrossRef]

36. Wang, Z.R.; Gong, B.; Wang, Z.G. Cyclic deformation behavior of Cu-30wt $\%$ Zn single crystals oriented for single slip-I. Cyclic deformation response and slip band behavior. Acta Mater. 1998, 47, 307-315. [CrossRef]

37. Niewczas, M. Latent hardening effects in low cycle fatigue of copper single crystals. Philos. Mag. 2013, 93, 272-303. [CrossRef]

38. Li, X.W.; Wang, X.M.; Yan, Y.; Guo, W.W.; Qi, C.J. Effect of pre-fatigue on the monotonic deformation behavior of a coplanar double-slip-oriented $\mathrm{Cu}$ single crystal. Metals 2016, 6, 293. [CrossRef]

39. Ma, X.G.; Chen, J.; Liu, Y.Z.; Wang, X.H.; Huang, S.Y.; Chen, Z. Effect of short-range order on microstructure, texture and strain hardening of cold drawn Cu-10at.\% Mn alloy. Mater. Charact. 2018, 135, 32-39. [CrossRef]

40. Gutierrez-Urrutia, I.; Raabe, D. Dislocation and twin substructure evolution during strain hardening of an Fe-22wt.\% Mn-0.6wt.\% C TWIP steel observed by electron channeling contrast imaging. Acta Mater. 2011, 59, 6449-6462. [CrossRef]

(C) 2019 by the authors. Licensee MDPI, Basel, Switzerland. This article is an open access article distributed under the terms and conditions of the Creative Commons Attribution (CC BY) license (http:/ / creativecommons.org/licenses/by/4.0/). 